\title{
Estimation of water use of mature coconut (Cocos nucifera L.) cultivars (CRIC 60 and CRIC 65) grown in the low country intermediate zone using the compensation heat pulse method (CHPM)
}

\author{
Wasantha S. Madurapperuma ${ }^{1}$, W.A.J.M. de Costa ${ }^{2}$ U.R. Sangakkara ${ }^{2}$ \& C. Jayasekara ${ }^{3}$ \\ 1 Plant Physiology Division, Coconut Research Institute, Bandirippuwa Estate, Lunuwila. \\ 2 Department of Crop Science, Faculty of Agriculture, University of Peradeniya, Peradeniya. \\ 3 Coconut Research Institute, Bandirippuwa Estate, Lunuwila.
}

\begin{abstract}
The compensation heat pulse method (CHPM) was used to determine the diurnal variation and daily total water use of two coconut varieties (i.e. CRIC 60 and CRIC 65) growing on two contrasting land suitability classes (i.e. S2, Kurunegala series, and S4, Kuliyapitiya series) in the lowcountry intermediate zone (IL1) of Sri Lanka. The average daily total sap flow $\left(\mathrm{F}_{\mathrm{d}}\right)$ of CRIC 60 and CRIC 65 on S2 were 120 and $90 \mathrm{~L} \mathrm{~d}^{-1}$ while on S4 it was 92 and $79 \mathrm{~L} \mathrm{~d}^{-1}$ respectively. Palms on $\mathrm{S} 2$ showed higher $\mathrm{F}_{\mathrm{d}}$ than those growing on S4, with $27 \%$ and $15 \%$ increases in CRIC 60 and CRIC 65 respectively. The greater soil depth and the water holding capacity of S2 and the consequently greater trunk water storage of palms growing on S2 were the probable causes. CRIC 60 showed $24 \%$ and $22 \%$ greater $\mathrm{F}_{\mathrm{d}}$ than CRIC 65 on $\mathrm{S} 2$ and $\mathrm{S} 4$ respectively. On $\mathrm{S} 4$, this was primarily because of the higher leaf area per palm of CRIC 60. On S2, both varieties had similar leaf area, indicating that varietal differences in root water absorption and stem water conductance capacities were probably causing the varietal difference in $\mathrm{F}_{\mathrm{d}}$. On the majority of measurement days, all palms reached their maximum hourly sap flux $\left(\mathrm{F}_{\mathrm{m}}\right)$ after $1000 \mathrm{~h}$, maintained it until $1600 \mathrm{~h}$ followed by a rapid decline. $F_{d}$ showed a strong positive correlation with $F_{m}$. A significant positive correlation between daily total sap flow and total leaf area per palm provided strong validation to the results obtained.
\end{abstract}

Keywords: Cocos nucifera L., compensation heat pulse method, daily total sap flow, maximum hourly sap flux, sap wood area.

\section{INTRODUCTION}

Coconut (Cocos nucifera L.) is a tree crop which has a variety of uses as food, fibre and wood ${ }^{1,2}$. Coconut palms are highly productive and are capable of supporting a large leaf area, particularly in the tropics where temperatures are high and radiation and rainfall are abundant. Consequently, they are significant users of water. Coconut in Sri Lanka is cultivated across three main agro-ecological regions (AER); i.e. the wet zone (WZ), the intermediate zone (IZ) and the dry zone (DZ). While WZ and IZ have about $40 \%$ each of the total planted area, the DZ has only $20 \%$, primarily because of its low rainfall and soil water availability ${ }^{3}$. Because coconut is grown as a rainfed crop, drought causes significant reduction in coconut yields by adversely affecting the physiology of the palm. Significant soil water deficits develop in intermediate and dry zones during the periods between the two monsoons of the year. Droughts can occur even in the wet zone in some years. As a result of the potentially high water use of coconut and its relatively shallow, fibrous root system, its key physiological processes and nut yield are adversely affected by drought ${ }^{4,6}$. Hence, the beneficial effects of irrigation on nut production have been reported by many workers $^{5,7-9}$.

There have been only a few studies in the past to estimate the water requirement of coconut. For example, Copeland ${ }^{10}$ estimated that a coconut palm transpires about $28-74 \mathrm{~kg}$ of water $\mathrm{d}^{-1}$ depending upon weather conditions, age and stage of growth. In 1948, investigations by Reyne ${ }^{11}$ (as cited in Ohler ${ }^{12}$ ) showed that under favourable conditions a mature coconut palm transpires $\sim 200 \mathrm{~L}$ of water $\mathrm{d}^{-1}$. Jayakumar et al. ${ }^{13}$ quantified the consumptive water use of coconut by using volumetric lysimeters and found that the consumptive 
water use of 6 year old young palms with a leaf area index of 2.4 ranged from 2.7 to $4.1 \mathrm{~mm} \mathrm{~d}^{-1}$. Jayasekara and Jayasekara ${ }^{14}$ conducted several field experiments to asses the nutrient and water balances of coconut under different soil-plant management systems. According to their results, an adult coconut palm with 35 fronds (leaf area of $\sim 150 \mathrm{~m}^{2}$ ) transpired $30-120 \mathrm{~L}$ of water $\mathrm{d}^{-1}$ depending on the atmospheric demand and soil water content. Jayasekara ${ }^{15}$ used measurements from a nullbalance porometer (Li-Cor 1600, Li-Cor Inc., Nebraska, USA.) to estimate total canopy transpiration of coconut in saturated soils and found a value of $120 \mathrm{~L} \mathrm{palm}^{-1} \mathrm{~d}^{-1}$. Yusuf and Varadan ${ }^{16}$ estimated the water consumption by tall coconut in India as $115 \mathrm{~L} \mathrm{~d}^{-1}$ in summer and $55 \mathrm{~L} \mathrm{~d}^{-1}$ in winter. Ramadasan and Kasturi Bai ${ }^{17}$ calculated transpirational water loss of dwarf coconut varieties with a leaf area of $140 \mathrm{~m}^{2}$ as $114 \mathrm{~L} \mathrm{~d}^{-1}$. However, these estimates were done based on the atmospheric demand and the soil water status which fluctuate significantly both within and between days. Furthermore, estimates of canopy water use by measurements at the leaf scale could introduce significant up-scaling errors.

Transpiration by a whole tree can easily be estimated by measuring stem sap flow ${ }^{18,19}$. The recent study ${ }^{20}$ carried out to quantify the energy budget and water transfer within a tropical coconut plantation in Vanatu, South Pacific reported a transpiration of about $93-160 \mathrm{~kg}$ water $\left(1.3-2.3 \mathrm{~mm} \mathrm{day}^{-1}\right) \mathrm{palm}^{-1} \mathrm{~d}^{-1}$. They have used Grainer's sapflow $^{21}$ method to measure plant transpiration which has often been reported to be a consistent method ${ }^{22,23}$.

In Sri Lanka, as a pre-requisite to devise appropriate drought mitigation measures, there is an urgent need to quantify the variation of transpirational water use of coconut and identify its controlling factors. Therefore, the main objective of the present study was to quantify the water use by a coconut palm based on transpiration of two contrasting coconut varieties on two different land suitability classes in the intermediate zone. To understand the transpiration of palms, it is important to monitor the palms continuously over a period of time. Use of sap flow methods allows such continuous monitoring of transpiration. The most common and feasible sap flow techniques for the large trees are the heat pulse and heat dissipation methods. The heat pulse method can be used to measure sap flow with minimal disruption to the sap stream ${ }^{24-26}$ while providing good time resolution.

Here, what is measured is the rate of transfer of a heat pulse given to the sapwood by the xylem sap flow. The compensation heat pulse method (CHPM) has been widely used ${ }^{27-29}$ on a variety of crops such as olive (Olea europaea L.) ${ }^{30-33}$, apple (Malus sylvestris Miller ${ }^{34-36}$, kiwi fruit (Actinidia deliciosa Chev. $)^{34-36}$, grapes $(\text { Vitis vinifera L. })^{36}$, pear (Pyrus serotina) $)^{37}$, apricot (Prumus armeniaca L.) $)^{38}$ and woody trees ${ }^{39,40}$. In general, transpiration measurements using the heat pulse method have shown good agreement with simulated whole-tree transpiration levels ${ }^{41-44}$.

So far, there have not been any attempts to estimate the whole plant water use of the coconut palm using heat pulse sap flow measurement. Therefore, in the present study, the CHPM was used to measure the diurnal patterns of stem sap flow and the whole plant water use of two coconut varieties grown in different land suitability classes in the low country intermediate zone of Sri Lanka.

The land suitability classes for coconut cultivation are defined primarily on the basis of their differentiation into horizons, their physical properties and water holding characteristics $^{3}$. Therefore, it is highly probable that soil water availability as determined by the land suitability class could influence the overall water use and its variation with time during a drought period. The soil water availability also influences the standing leaf area of a coconut palm and its water storage in the trunk, both of which are important determinants of transpiration ${ }^{15}$. Furthermore, water use of different coconut varieties may be responding differently to variation in land suitability and the consequent differences in soil water availability because of their inherent genetic variation in water relations characteristics ${ }^{14,15,17,45}$. These could include inter-varietal variation in canopy leaf area, stomatal physiology, root length density and the capacities for water absorption by the root system and translocation of water through the xylem.

This study also includes a preliminary investigation to identify the suitable trunk depth to install the sap flow probes where the thermal contacts between probes and xylem tissues are at the optimum level to detect the flow rates.

\section{METHODS AND MATERIALS}

Experimental location: The study was carried out in a coconut plantation at Wellawa $\left(7^{\circ} 35^{\prime} 09 \mathrm{~N}, 80^{\circ} 20^{\prime} 57 \mathrm{E}\right.$ and elevation $97-101 \mathrm{~m}$ amsl) representing the lowcountry intermediate zone; IL-1a agro-ecological zone, which receives a mean annual precipitation of $1400 \mathrm{~mm}$. The weather during the experiment was characterized by dry, generally clear days. However, intermittent rains and clouds occurred during some days of measurement. Air temperature and relative humidity of the area varied from $27^{\circ}$ to $34^{\circ} \mathrm{C}$ and from 62 to $90 \%$ respectively with 
the mean daily evapotranspiration being $3.49 \mathrm{~mm} \mathrm{~d}^{-1}$. Solar radiation and daily sunshine hours of the area were in the range of 800 to $1200 \mathrm{Wm}^{-2}$ and 2 to $10 \mathrm{~h} \mathrm{~d}^{-1}$ respectively.

Coconut varieties and land suitability classes: Twenty year old palms from 2 coconut varieties, i.e. CRIC 60 and CRIC 65, which are the 2 main cultivars grown in Sri Lanka, were used. Both varieties are improved hybrids, with CRIC 60 (Tall x Tall) being a tall variety and CRIC 65, a dwarf variety (Dwarf x Tall). Hence, the general characteristics as well as the performances of these 2 varieties are different from each other. CRIC 60, which is a relatively hardy palm, is considered to be tolerant to pests, diseases and drought and is recommended for planting in all coconut growing areas of the country. CRIC 65, on the other hand, is sensitive to environmental changes, especially water stress and is more specific in its requirements than the tall form. Unlike CRIC 60, CRIC 65 is recommended for planting only in favourable environments, preferably with irrigation during drought, on well-drained soils of good texture and sufficient depth. Due to these two contrasting characters, CRIC 60 and CRIC 65 were selected for the experiment.

Two palms from each variety (Table 1) were selected for sap flow measurements in 2 land suitability classes, namely, S2, which is a suitable land for coconut and $\mathrm{S} 4$, which is less suitable. The soils were identified as belonging to Kurunegala series (S2) and Kuliyapitiya series (S4) $)^{46,47}$. Soils of Kurunegala series occur on flat to undulating landforms and are moderately weathered, deep, imperfectly to poorly drained. According to the local soil classification, this soil series is classified under Red Yellow Podzolic soil group with soft and hard laterites ${ }^{46}$. According to the USDA soil taxonomy, this soil group is named as Plintudults fine loamy, non calcarious $\mathrm{s}^{47}$. The Kuliyapitiya series, on the other hand, has undulating to hilly topography. The texture of the surface soil is sandy clay loam, which changes from gravelly sandy clay loam, to clay loam and sandy clay loam in deeper horizons. According to the local classification ${ }^{46}$, this

Table 1: Characteristics of the palms used for sap flow determination and period of measurements done in each palm in year 2008

\begin{tabular}{cccccr}
\hline $\begin{array}{c}\text { Land suitability } \\
\text { class }\end{array}$ & Palm & $\begin{array}{c}\text { Leaf area } \\
\mathrm{m}^{2}\end{array}$ & $\begin{array}{c}\text { Circumference } \\
\text { at } 5 \mathrm{ft}(\mathrm{cm})\end{array}$ & $\begin{array}{r}\text { Sap wood } \\
\text { area }\left(\mathrm{cm}^{2}\right)\end{array}$ & $\begin{array}{r}\text { Period of } \\
\text { measurement }\end{array}$ \\
\hline \multirow{3}{*}{ S2 } & & & & & \\
& TT-P1 & 226 & 84 & 480 & 31 Jan - 7 Feb \\
& TT-P2 & 220 & 85 & 491 & $7-14 \mathrm{Feb}$ \\
& DT-P1 & 217 & 82 & 456 & $14-21 \mathrm{Feb}$ \\
& DT-P2 & 214 & 83 & 468 & $13-19 \mathrm{Mar}$ \\
S4 & TT-P1 & 190 & 80 & 430 & $24-31 \mathrm{Jan}$ \\
& TT-P2 & 194 & 81 & 438 & $21-29 \mathrm{Feb}$ \\
& DT-P1 & 175 & 74 & 380 & 29 Feb - 7 Mar \\
& DT-P2 & 174 & 72 & 343 & $7-14 \mathrm{Mar}$ \\
\hline
\end{tabular}

Table 2: Important soil characteristics of the major horizons of S2 and S4 land suitability classes

\begin{tabular}{lllllll}
\hline $\begin{array}{c}\text { Land suitability class/ } \\
\text { Soil series }\end{array}$ & $\begin{array}{c}\text { Depth } \\
\mathrm{cm}\end{array}$ & $\begin{array}{c}\text { Profile } \\
\text { identified }\end{array}$ & $\begin{array}{c}\text { Textural } \\
\text { class }\end{array}$ & OM \% & $\begin{array}{c}\text { Bulk } \\
\text { density } \\
\left(\mathrm{g} \mathrm{cm}^{-3}\right)\end{array}$ & $\begin{array}{c}\text { Porosity } \\
\left(\mathrm{cm}^{3} / \mathrm{cm}^{3}\right)\end{array}$ \\
\hline S2 & $0-15$ & Ap & Sandy loam & 1.39 & 1.12 & 0.57 \\
Kurunegala series & $15-36$ & Ap2 & Sandy clay loam & 1.06 & 1.31 & 0.51 \\
& $36-76 / 90$ & Ab & Sandy clay loam & 0.73 & 1.44 & 0.46 \\
& $76 / 90 \mathrm{~cm}-128$ & Ab & Sandy clay loam & 0.15 & 1.41 & 0.47 \\
S4 & $128-147$ & C & Sandy clay & 0.07 & 1.65 & 0.37 \\
Kuliyapitiya series & $0-10$ & Ap & Sandy clay loam & 2.18 & 1.01 & 0.62 \\
& $10-28$ & Ap2 & Gravely sandy clay loam & 2.00 & 1.39 & 0.48 \\
& $28-50 / 70$ & B & Clay loam & 0.46 & 1.51 & 0.43 \\
\hline
\end{tabular}


soil also is named as Red Yellow Podzolic, which is classified as Typic Hapludults, fine loamy non calcarious isohyperthemic by the USDA classification ${ }^{47}$. The 2 land suitability classes were in the same coconut plantation about $1.5 \mathrm{~km}$ apart from each other. Hence, it is assumed that all palms experienced similar climatic conditions. Palms were planted at a spacing of $8.3 \mathrm{~m} \times 8.3 \mathrm{~m}$ in a square planting arrangement.

Four major soil horizons were identified in the S4 land suitability class while five were detected in S2. Their important soil properties identified in the experiment are given in Table 2 . The gravimetric soil moisture contents at 40 and $100 \mathrm{~cm}$ depths in S2 and S4 soils were measured at the beginning and at the end of sap flow measurements in each palm during the measurement period.

Measurement of heat pulse velocity: The CHPM $^{24,25,29,41,48,49}$ was used to measure the heat pulse velocity of the selected palms. SF 100 standard probe set of CHPM was used in this experiment (Greenspan Technology Pvt Ltd, Warwick, Australia). Probes were installed in stems at a height of $1.5 \mathrm{~m}$ from the ground level in all palms by drilling the palm using an electric drill. A drill guide was used when drilling the holes to make sure the holes were drilled parallel to each other and at the correct spacing. Drilling was done slowly to prevent excessive tearing of wood fibres along the length of the hole. Based on the results of a separate study to determine the most suitable trunk depth to install probes (reported elsewhere in this paper), probes were installed at a depth of $7.5 \mathrm{~cm}$ from the outer periphery. The SF 100 sap flow sensor utilizes two probe sets, each with a heater probe and 2 sensor probes (Figure 1). The upstream sensor probe is located $5 \mathrm{~mm}\left(\mathrm{X}_{\mathrm{u}}\right)$ below the heater probe and the downstream probe is located $10 \mathrm{~mm}\left(\mathrm{X}_{\mathrm{d}}\right)$ above the heater probe. On each probe set, there are 2 temperature sensors spaced $5 \mathrm{~mm}$ apart (i.e. S1 and S2 in Figure 1).

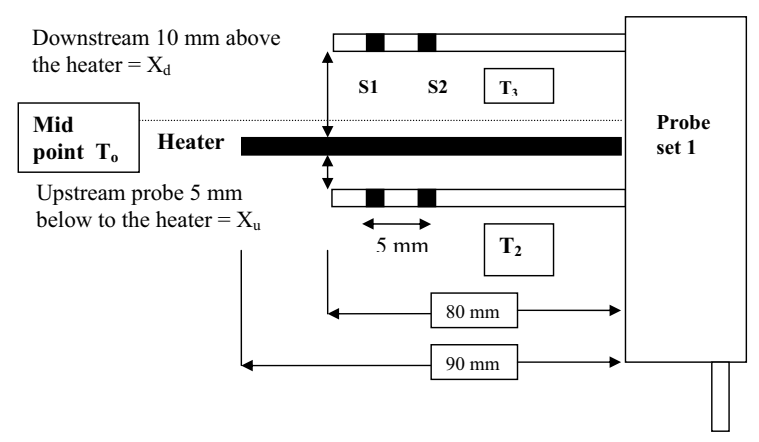

Figure 1: Layout of a single probe set of the CHPM (User Manual, Sap Flow Sensor. Version 2. Greenspan Technology Pvt. Ltd.)
$X_{u}$ and $X_{d}$ represent the distances of the upstream and downstream sensors respectively from the heater.

Theory of the CHPM is described in detail by many researchers ${ }^{24,25,29,39,41}$. Briefly, 2 probes (1.9 mm diameter) containing temperature sensors in a stainless steel tubing, are inserted radially to equal depths into the sapwood and positioned above and below a similarly inserted line heater probe. The temperature probes are spaced asymmetrically from the heater $\left[5 \mathrm{~mm}\right.$ below $\left(\mathrm{T}_{2}\right)$ and $10 \mathrm{~mm}$ above $\left(\mathrm{T}_{3}\right)$ the heater] such that the mid-point of the two probes $\left(\mathrm{T}_{\mathrm{o}}\right.$ ) is located $2.5 \mathrm{~mm}$ above the heater (Figure 2). In each palm, 2 sensors were installed at the same depth but in opposite directions, to ensure even coverage of the cross-section. The heater probe was used to inject a small pulse of heat into the sap wood over a period of $1.8 \mathrm{~s}$ at a frequency of $10 \mathrm{~min}$ through a programmed data logger. The heat pulse is propagated through the sapwood, both by conduction through the wood and sap matrix and by convection with the moving sap stream. Following the heat pulse, wood and sap are heated in pulses and the resulting sapwood temperature increase is monitored above and below the heater. Moving sap carries the heat pulse downstream (i.e. up the stem), and when the centre of the heat pulse is transferred to the mid point between the 2 sensors $(2.5 \mathrm{~mm}$ downstream from the heater in the present study), both temperature sensors are warmed to the same temperature (i.e. thermal equilibrium). The logger is programmed to record the time taken for the heat pulse to travel up to the mid point ( $t_{0}$ in seconds), which was finally used to calculate heat pulse velocity $\left(V_{\mathrm{h}}\right.$ in $\left.\mathrm{cm} \mathrm{h}^{-1}\right)$ as,

$V_{h}=\frac{(X d+X u)}{2 t_{0}} \times 3600$

where $X_{\mathrm{d}}$ and $X_{\mathrm{u}}$ are the respective distances (in $\mathrm{cm}$ ) from the heater to the downstream and upstream temperature

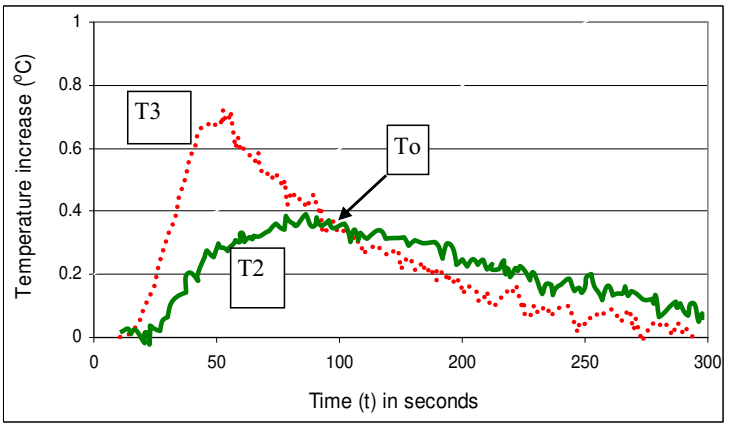

Figure 2: Temperature plot for the CHPM (User Manual, Sap Flow Sensor. Version 2. Greenspan Technology Pvt. Ltd.) 
probes. $X_{\mathrm{u}}$ is denoted as a negative number because of its location on the opposite side of the heater.

CHPM has provisions to correct for wounding to the trunk that may occur during the installation of probes. Corrections for wounding were done by taking the average wound diameter around the drill holes of each probe set. Wound widths were measured by anatomical investigations, according to the method described by Barrett et al. ${ }^{50}$ Corrections for wounding were done according to the equation given by Swanson and Whitfield ${ }^{24}$ as,

$V_{\mathrm{c}}=a+b V_{\mathrm{h}}+c V_{\mathrm{h}}^{2}$

where $V_{\mathrm{c}}$ is corrected heat pulse velocity and $a-c$ are wound correction coefficients for given wound widths.

Conversion of heat pulse velocity to sap velocity: Sap velocity $\left(V_{\mathrm{s}}\right)$ was calculated from $V_{\mathrm{c}}$ using an equation modified from Marshall ${ }^{29}$ as given by Barrett et al. ${ }^{50}$.

$\mathrm{V}_{s}=\frac{\mathrm{V}_{c} \rho_{b}\left(\mathrm{c}_{s}+\mathrm{m}_{c} \mathrm{c}_{w}\right)}{\rho_{w} \mathrm{c}_{w}}$

where $\rho_{b}$ is the basic density of wood (dry weight / fresh volume), $\rho_{w}$ is the density of water (i.e. xylem sap), $c_{\mathrm{s}}$ is the estimated specific heat capacity of wood $1200 \mathrm{~J} \mathrm{~kg}^{-1}{ }^{\circ} \mathrm{C}^{-1}{ }^{51}, c_{\mathrm{w}}$ is the specific heat capacity of the water $4182 \mathrm{~J} \mathrm{~kg}^{-1}{ }^{\circ} \mathrm{C}^{-1} 52$ and $m_{\mathrm{c}}$ is the water content of sapwood. The sapwood area of the tree stem and the sap wood properties were determined from an analysis of trunk cores taken at the end of the experiment near probe installations. Fresh weight, dry weight and fresh volume were used to calculate $m_{\mathrm{c}}$ and $\rho_{\mathrm{b}}$, and also the true value of thermal diffusivity $(k)$ according to the equation given by Marshall ${ }^{29}$. Moisture content was determined by weighing samples using a precision electronic balance before and after oven drying at $60^{\circ} \mathrm{C}$ for $24 \mathrm{~h}$ and fresh volume was determined by immersing samples in distilled water and applying the Archimedes' principle.

Measurements from the two probe sets in each palm were averaged to give a single value. Measurements of sap velocity recorded at $10 \mathrm{~min}$ intervals were cumulated to derive hourly averages of sap velocity $\left(\mathrm{cm} \mathrm{hr}{ }^{-1}\right)$. Volumetric sap flow $\left(\mathrm{L} \mathrm{hr}^{-1}\right)$ was calculated by multiplying hourly average sap velocity with trunk cross-sectional area. Use of the trunk cross-sectional area in this conversion is based on results of the separate study to investigate sap flow at different trunk depths and recent literature on the presence and activity of vascular bundles across a trunk cross section of coconut ${ }^{20}$.
A detailed justification of this decision is given elsewhere in this paper. Daily total transpiration (i.e. water use) was calculated by taking the sum of hourly volumetric sap flow of a given day.

Determination of suitable depth for probe installation: A set of coconut palms from the same plantation was used to study the suitable depth for the probe installation before starting the experiment. Depths of $1-2 \mathrm{~cm}$ from the outer stem were not used for the calculation of volumetric sap flow as they contain the bark and cortex tissue which do not have any vascular bundles. Four different depths, i.e. $6.0,6.5,7.0$ and $7.5 \mathrm{~cm}$, were used to determine the suitable depth for probe installation. Probe installation at depths higher than $6 \mathrm{~cm}$ (i.e. closer to the outer periphery) did not give proper signals. Depths beyond $7.5 \mathrm{~cm}$ were not measured based on the results obtained at 7.0 and $7.5 \mathrm{~cm}$ (shown elsewhere in this paper), which indicated that the best thermal contact between probes and xylem tissues were obtained in this region. Probes were installed at the same height (1.5 m from the ground level) in the same palm and at all installations with about $10-15 \mathrm{~cm}$ to left/right away from the previous installations. At each installation depth, data were collected sequentially for a period of one week. Core samples were taken at the end of all measurements along the probe length. Three samples at each depth of the trunk were taken for the measurements of wood properties.

Sap flow measurement in coconut palms: Sap flow measurements of coconut palms were conducted sequentially during January - March 2008. At the end of the each sap flow measurement, 3 trunk core samples at the distal end of the probe depth were taken for the calculation of sapwood properties. The average values of the thermal diffusivity and $\mathrm{V}_{\mathrm{s}}$ conversion factor were used in the final calculation of volumetric sap flow. Gravimetric soil moisture content $(\theta \mathrm{g})$ of S2 and S4 soils at 40 and $100 \mathrm{~cm}$ depths were measured at the beginning and end of sap flow measurements of each palm.

\section{RESULTS AND DISCUSSION}

\section{Sap flow measured at different depths of the trunk cross section}

Hourly sap flow rates measured at all depths along the radius of the stem (Figure 3 ) showed a typical bell shaped diurnal pattern. However, the two diurnal variations obtained at the depths of 7.0 and $7.5 \mathrm{~cm}$ were almost similar in quantity and the pattern was indistinguishable from each other on certain days ( $4^{\text {th }}$ day). Hourly sap flow rates at 6.5 and $6.0 \mathrm{~cm}$ depths were lower than those at 7.0 and $7.5 \mathrm{~cm}$. 
Ohler $^{12}$ and Tomlinson ${ }^{53}$ have found that vascular bundles are distributed across the whole cross section of a coconut trunk. Roupsard et al. ${ }^{20}$ found that the whole cross-sectional area of a coconut palm (except the bark) was equally effective in conducting water. This is understandable as coconut is a monocot, where vascular bundles are not arranged in concentric rings as in dicots. However, Roupsard et al. ${ }^{20}$ also found that the packing density of vascular bundles varied across the stem cross section. The vascular bundles were less densely packed in regions closer to the middle of the trunk and closer to the outer periphery. Therefore, it is highly likely that in the present study, the lower sap flow velocities observed at 6.0 and $6.5 \mathrm{~cm}$ depths were due to the poor thermal contact between heat pulse needles and vascular bundles, which were less densely packed at these depths. Such instances have been reported by Barrett et al..$^{50}$ as well. On the other hand, the higher sap flow velocities at 7.0 and $7.5 \mathrm{~cm}$ depths indicated that there was good contact between probes and vascular bundles, which were more densely packed in this region. Hence, it is safe to assume that the lower sap flow velocities that were observed at 6.0 and $6.5 \mathrm{~cm}$ depths were not because of reduced sap

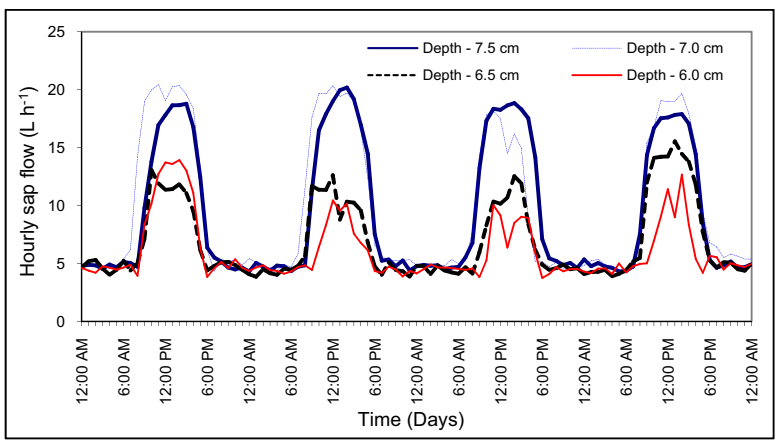

Figure 3: Diurnal variation of hourly sap flow when the sensor probes were inserted at different depths of the stem cross section

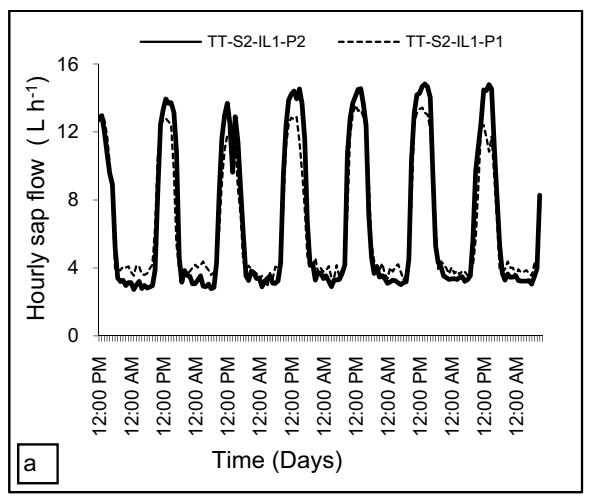

flow at these depths but due to the poor probe-vascular bundle contact resulting from their lower packing density. Accordingly, the observed sap flow velocity at $7.5 \mathrm{~cm}$ was taken as representative of the entire stem cross section and volumetric sap flow calculations were done assuming a uniform sap flow rate in the whole crosssectional area of the coconut trunk.

\section{Relationship between sap flow and leaf area}

The close relationship between leaf area and transpiration has been demonstrated by other researchers to validate the sap flow measurement method ${ }^{49}$. As no absolute measurements were used to determine transpiration, in this study also the relationship between the sap flow and leaf area of a single palm was used to test the consistency and accuracy of sap flow measurements. A strong, positive correlation between sap flow and leaf area was observed for individual palms (Figure 4). This indicates the suitability of CHPM for measurements of whole palm transpiration in coconut. This validated the measurement procedure and suggests that the results were free of external environmental noise. This relationship also

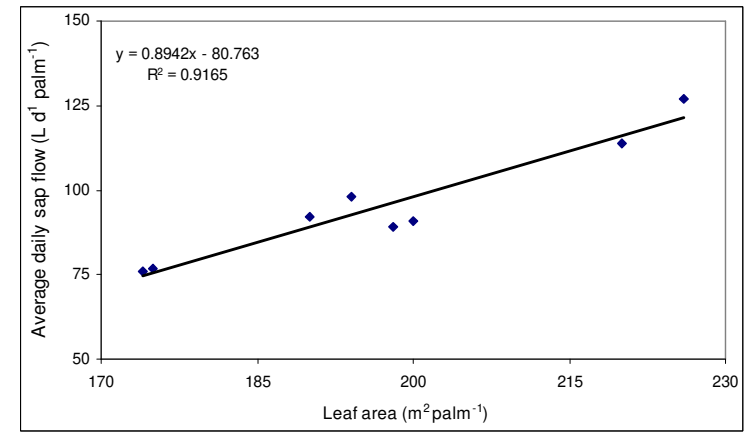

Figure 4: The relationship between average daily sap flow and leaf area of the palms used in the study

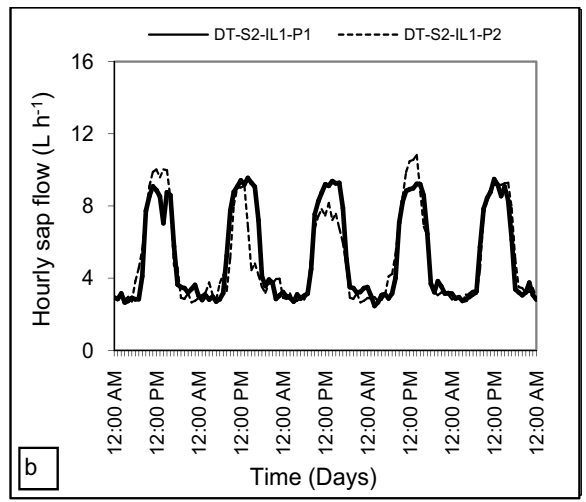

Figure 5: Diurnal variation of hourly sap flow of selected TT (a) and DT (b) palms grown on S2 soils in IL1 (two palms indicated by the two lines) over periods of 7 and 5 days respectively 
provides strong support for the assumption of uniform sap flow velocities throughout the whole trunk cross section in converting sap flow velocity to volumetric sap flow.

\section{Soil moisture measurements}

Soil moisture content $(\theta \mathrm{g})$ of $\mathrm{S} 2$ soils varied between 9-16 \% and $10-19 \%$ respectively at 40 and $100 \mathrm{~cm}$ and in S4 soils it varied between $5.0-6.5 \%$ and $10-13 \%$ respectively at the two depths.

\section{Diurnal course of sap flow in TT and DT palms grown on S2 soils}

Sap flow in measured palms of both varieties showed a similar diurnal pattern (Figure 5). However, the quantity of sap flow differed between varieties, with TT having a greater sap flow than DT. The maximum hourly sap flow $\left(\mathrm{F}_{\mathrm{m}}\right)$ of TT was about $14 \mathrm{~L} \mathrm{hr}^{-1}$ (Figure 5a) whereas in DT it was $10 \mathrm{~L} \mathrm{hr}^{-1}$ (Figure 5b).

Figure 6 illustrates the diurnal time course of the sap flow for two TT (Figure 6a) and two DT (Figure 6b) palms, on the days that they showed $F_{m}$ during the measurement period. Both varieties achieved their respective $F_{m}$ after $1100 \mathrm{~h}$. Thereafter, the sap flow of both varieties was maintained at $\mathrm{F}_{\mathrm{m}}$ for the next 5-6 hrs and declined rapidly after $1600 \mathrm{~h}$. This pattern of diurnal variation of sap flow is typical for plants growing on an adequate supply of water. It closely follows the variation of solar irradiance with the progress of the day with the sap flow increasing with increasing irradiance during morning until mid-day and decreasing in the afternoon with decreasing irradiance. However, on certain days, sap flow of DT started around $0600 \mathrm{~h}$ and increased continuously until $1400 \mathrm{~h}$ (e.g. P1 of DT). After reaching the maximum sap flow at $1400 \mathrm{~h}$, it declined rapidly until $1800 \mathrm{~h}$. This rapid decline from early afternoon onwards could be the result of higher transpiration rates during the morning, which would have diminished the water reserves accessible to the root system quickly. When transpiration rate exceeds the rate of water supply through root water absorption, high transpiration rates can still be maintained by drawing water from trunk storage tissues (i.e. water capacitors). It is possible that this may be happening in these coconut palms as well. The rapid

Table 3: Daily total sap flow $\left(F_{d}\right)$ of different palms during the period of sap flow measurements (day 1, 2, 3, 4, 5 are not the same calendar days for all palms)

\begin{tabular}{ccrrrrr}
\hline $\begin{array}{l}\text { Suitability } \\
\text { class }\end{array}$ & Palm & $\begin{array}{c}\text { Day-1 } \\
\left(\mathrm{L} \mathrm{d}^{-1}\right)\end{array}$ & $\begin{array}{r}\text { Day-2 } \\
\left(\mathrm{L} \mathrm{d}^{-1}\right)\end{array}$ & $\begin{array}{r}\text { Day-3 } \\
\left(\mathrm{L} \mathrm{d}^{-1}\right)\end{array}$ & $\begin{array}{r}\text { Day-4 } \\
\left(\mathrm{L} \mathrm{d}^{-1}\right)\end{array}$ & $\begin{array}{r}\text { Day-5 } \\
\left(\mathrm{L} \mathrm{d}^{-1}\right)\end{array}$ \\
\hline \multirow{3}{*}{ S2 } & TT-P1 & 116.7 & 117.9 & 135.5 & 129.2 & 135.7 \\
& TT-P2 & 104.9 & 115.5 & 123.2 & 125.2 & 125.7 \\
& DT-P1 & 86.3 & 94.6 & 94.4 & 89.3 & 91.4 \\
& DT-P2 & 97.7 & 79.3 & 79.1 & 96.4 & 94.8 \\
S4 & TT-P1 & 74.7 & 67.8 & 72.8 & 79.7 & 83.3 \\
& TT-P2 & 84.6 & 74.1 & 76.5 & 67.2 & 82.7 \\
& DT-P1 & 74.7 & 67.8 & 72.8 & 79.7 & 83.3 \\
& DT-P2 & 84.6 & 74.1 & 76.5 & 67.2 & 82.7 \\
\hline
\end{tabular}

Table 4: Daily total sap flow and maximum hourly sap flow (both averaged over 5 days) and the coefficient of determination $\left(\mathrm{R}^{2}\right)$ in the linear relationship between the two variables

\begin{tabular}{lcccc}
\hline $\begin{array}{l}\text { Suitability } \\
\text { class }\end{array}$ & Palm & $\begin{array}{c}\text { Daily total sap flux } \\
\left(\mathrm{L} \mathrm{d}^{-1}\right) \\
\text { (Average }-5 \text { days) }\end{array}$ & $\begin{array}{c}\text { Maximum hourly } \\
\text { sap flux }\left(\mathrm{L} \mathrm{hr}{ }^{-1}\right)\end{array}$ & R2 \\
(Average - 5 days) & \\
\hline \multirow{3}{*}{ S2 } & & & & \\
& TT-P1 & 127 & 14 & 0.8885 \\
& TT-P2 & 114 & 12 & 0.9233 \\
& DT-P1 & 91 & 9 & 0.9768 \\
& DT-P2 & 89 & 10 & 0.8213 \\
S4 & TT-P1 & 94 & 10 & 0.7825 \\
& TT-P2 & 96 & 11 & 0.7865 \\
& DT-P1 & 78 & 8 & 0.9275 \\
& DT-P2 & 78 & 9 & 0.8717 \\
\hline
\end{tabular}



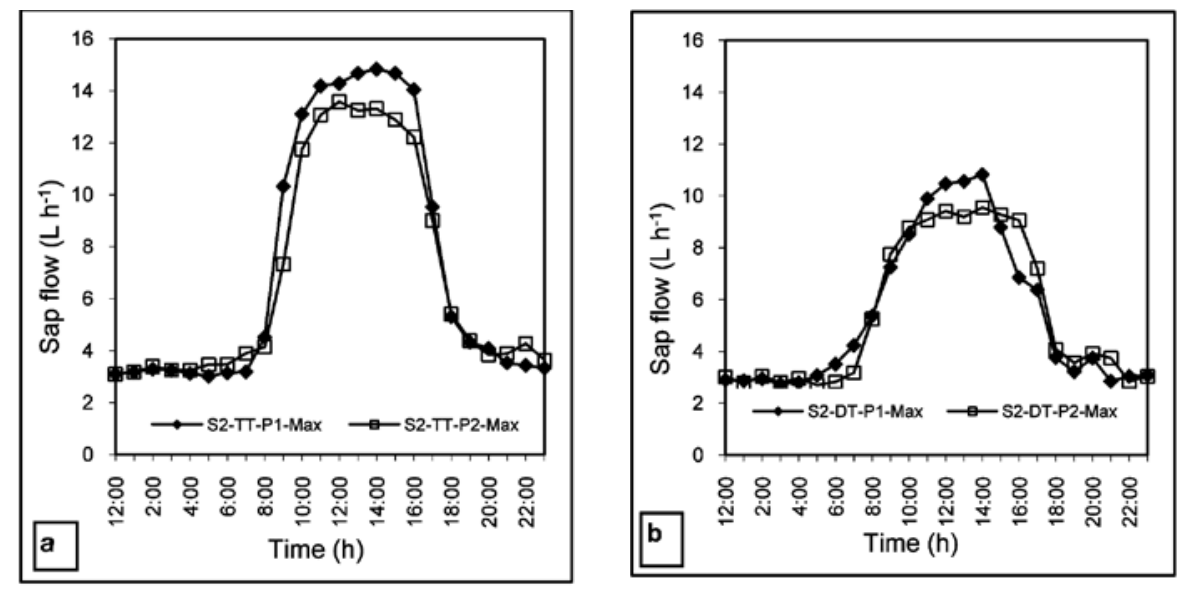

Figure 6: Diurnal variation of hourly sap flow within a day of two TT (a) and DT (b) palms (P1 and P2) (P1- filled symbol and P2- open symbol) when both palms showed maximum hourly sap flow
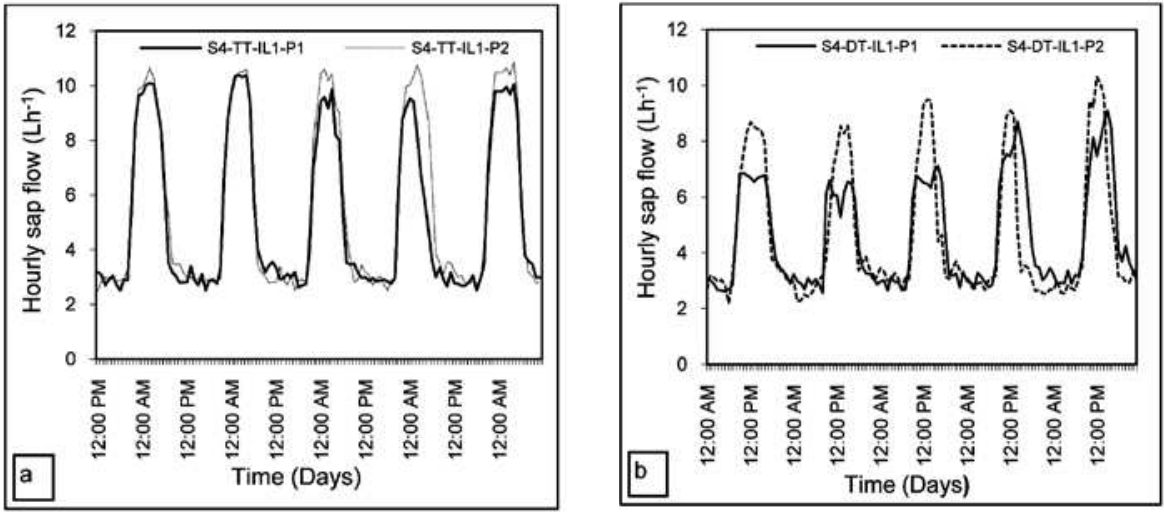

Figure 7: Diurnal variation of hourly sap flow of selected TT (a) and DT (b) palms grown on S4 soils in IL1 (two palms indicated by two lines) over period of 5 days
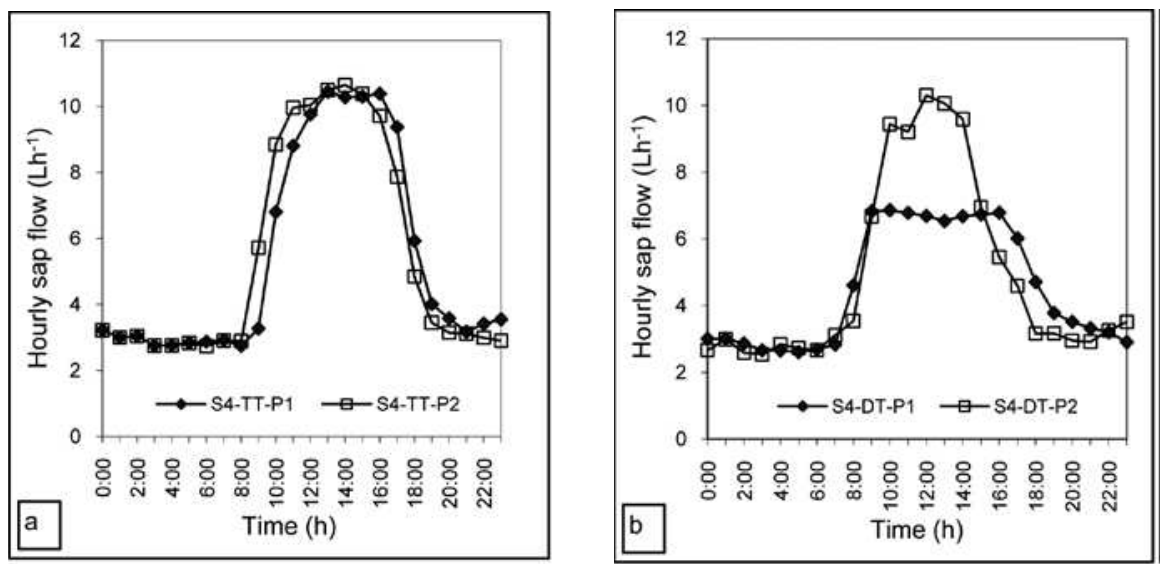

Figure 8: Diurnal variation of hourly sap flow within a day of two TT (a) and DT (b) palms (P1 and P2) (P1- filled symbol and P2- open symbol) grown on S4 soils on the days when both palms showed maximum hourly sap flow 
afternoon decline of sap flow in P1 of DT may indicate that the high morning transpiration rates had probably exhausted the supply of water from trunk storage tissues as well.

When the sap flow rates of both varieties were close to their respective maxima, DT showed an hourly sap flow of $8.5 \mathrm{~L} \mathrm{~h}^{-1}$ while TT showed over $12 \mathrm{~L} \mathrm{~h}^{-1}$ which was about $40 \%$ higher than DT. Daily total sap flow $\left(\mathrm{F}_{\mathrm{d}}\right)$ during the measurement period varied between 105 and $135 \mathrm{~L} \mathrm{~d}^{-1}$ palm$^{-1}$ in TT (Table 3) with an average daily sap flow of $120 \mathrm{~L} \mathrm{~d}^{-1}$. On the other hand, daily total sap flow of DT varied between 75 and $97 \mathrm{~L} \mathrm{~d}^{-1}$ with an average of $90 \mathrm{~L} \mathrm{~d}^{-1}$ (Table 3). This indicated that TT palms grown on S2 soils utilize 33\% more water than DT grown on the same soil.

$\mathrm{F}_{\mathrm{d}}$ showed a highly significant positive linear correlation with its respective $\mathrm{F}_{\mathrm{m}}$ in all palms measured (Table 4). This indicates that the period of $\mathrm{F}_{\mathrm{m}}$ (i.e. from around 1000 to $1600 \mathrm{~h}$ ) contributes to a substantial proportion of the daily transpiration of coconut palms.

\section{Diurnal course of sap flow measured in TT and DT palms grown in $\mathrm{S} 4$ soils}

On S4 soils also, both TT and DT varieties showed a similar pattern of sap flow variation (Figure 7) as observed in palms grown on $\mathrm{S} 2$ soils (Figure 5). There was an appreciable difference between the two DT palms in their patterns of sap flow (Figure 7b). This was probably because of the variation of environmental conditions (i.e. irradiance, vapour pressure deficit, air and canopy temperature etc.) during the days of measurement, which were different for the two palms. Figures 8 illustrates the diurnal time course of the sap flow for two TT (Figure 8a) and two DT (Figure 8b) palms, on the days that they showed $\mathrm{F}_{\mathrm{m}}$ during the measurement period. The $\mathrm{F}_{\mathrm{m}}$ of TT grown on $\mathrm{S} 4$ ranged between $9-11 \mathrm{~L} \mathrm{~h}^{-1}$ (Figure 8a) whereas DT showed a larger variation of $6-10 \mathrm{~L} \mathrm{~h}^{-1}$ (Figure $8 b$ ). Interestingly, on the days of lower $F_{d}$ in DT (Figure $8 \mathrm{~b}$ ), their $\mathrm{F}_{\mathrm{m}}$ were maintained for a longer period (i.e. about $7 \mathrm{~h}$ ) whereas on the days of higher $F_{d}$, the $F_{m}$ was maintained for a shorter period of about 3-4 h.

$\mathrm{F}_{\mathrm{d}}$ of TT palms grown on $\mathrm{S} 4$ ranged between $80-100 \mathrm{~L} \mathrm{~d}^{-1}$ (Table 3 ) with an average of $92 \mathrm{~L} \mathrm{~d}^{-1}$ which was $28 \%(\mathrm{p}<0.0001)$ lower than the corresponding value on S2 soils. This was primarily because of the lower maxima of hourly sap flow on the S4 soils. In the S4 soils, $F_{d}$ of DT ranged from 67 to $87 \mathrm{~L} \mathrm{~d}^{-1}$ (Table 3) with an average of $79 \mathrm{~L} \mathrm{~d}^{-1}$, which was $14 \%$ lower than corresponding sap flux of DT on S2.
Within this climatic zone, there was significant variation $(p<0.0001)$ between the two varieties in $F_{d}$, with TT showing $24 \%$ and $22 \%$ greater values than DT on S2 and $\mathrm{S} 4$ soils respectively. Also within the same climatic zone, land suitability class was also a factor that had a significant influence on the sap flow of both varieties. Both varieties had significantly greater sap flow in the suitability class S2 than in S4 with $27 \%$ and $15 \%$ increases in TT and DT respectively.

The waterflow necessary for transpiration is primarily absorbed through the root system and translocated via the xylem. When the rate of transpiration exceeds the rate of root water absorption, the transpiration stream is supplemented by water stored inside the trunk. The amount of water originating from storage is closely dependant on soil water availability and atmospheric demand for water. Differences in sap flow in a given variety between the two land suitability classes (Table 4) could have been due to variation in water storage capacity in the soil as well as in the trunk. The deeper S2 soils (Table 1) had a greater soil water storage, which allowed the palms growing on it to store a greater volume of water in their trunks. In contrast, the S4 soils were shallower and probably had a lower soil water storage allowing a lower trunk water storage in the palms that were growing on it. According to Somasiri et al. ${ }^{3}$, there is no significant moisture stress for coconut throughout the year on S2 soil. On the other hand in $\mathrm{S} 4$ soil, intensive moisture conservation practices are needed to alleviate the adverse impacts of drought that develop during the inter-monsoonal period.

Although the percentage differences in daily transpiration rates between the two varieties were almost similar on both land suitability classes (Table 4), they could have occurred because of different reasons. Varietal variation in leaf area was probably a significant factor contributing to the difference in sap flow between the two varieties on S4 soils (Tables 2 and 4), with TT, which had a greater leaf area, having a higher sap flow. However, both varieties had similar leaf areas on S2 soils. It is possible that TT, which had the greater daily sap flow, had a greater stomatal conductance $\left(\mathrm{g}_{\mathrm{s}}\right)$ than DT on these favourable S2 soils having a greater water storage capacity. This was confirmed by concurrent measurements of $\mathrm{g}_{\mathrm{s}}$ during the study period. Stomatal conductance of TT palms was $55 \%$ higher $\left(4.5 \mathrm{~cm} \mathrm{~s}^{-1}\right.$; values are mean of 12 replicate measurements) than that of DT $\left(2.02 \mathrm{~cm} \mathrm{~s}^{-1} ; \mathrm{n}=12\right)$ irrespective of the land suitability class.

It is also possible that a greater water absorption capacity through a deeper and a more extensive root system and more efficient water conductance through the 
trunk could have contributed to the higher $\mathrm{F}_{\mathrm{d}}$ of TT on S2 soils. While these factors could have contributed to the higher daily transpiration levels of TT on S4 soils, the higher leaf area of TT could also have been a stronger factor in determining the varietal differences in water use on $\mathrm{S} 4$ soils.

The time of reaching the maximum hourly sap flow and the duration of maintaining sap flow at the maximum flow rate, however, depends on several factors such as variety, soil factors and climatic factors.

\section{CONCLUSION}

The present study has shown, for the first time in Sri Lanka, that the CHPM can be used to assess the water use of coconut palms belonging to different varieties and growing on different land suitability classes. The daily total sap flow values determined in this experiment are within the range of the daily transpiration values calculated by other researchers for coconut ${ }^{14-16,20}$. Results also indicate that the water use of coconut is determined not only by plant factors but also by soil and climatic factors. The diurnal pattern in sap flow measurements clearly show how the sap flow rate changes with time of the day. This information is highly useful in in-depth investigations of plant water relations and in irrigation scheduling of coconut. The present work also highlights the possible contribution of stem water storage in determining the water use of coconut. This is an aspect which needs further investigation.

\section{Acknowledgement}

Mr. L.R.S. de Silva, senior technical officer of the Coconut Research Institute is gratefully acknowledged for the assistance extended in installation of sap flow probes in palms.

\section{References}

1. Ohler J.G. (1999). The coconut palm. In: Modern Coconut Management, Palm Cultivation and Products. pp. 11- 26, Intermediate Technology Publications, London, Food \& Agriculture Organization and in Collaboration with University of Leiden, Rome, Italy.

2. Menon K.P.V. \& Pandalai K.M. (1958). The Coconut Palm: A Monograph. Indian Central Coconut Committee, Ernakulam, India.

3. Somasiri L.L.W., Nadarajah N., Amarasinghe L. \& Gunathilake H.A.J. (1994). Land Suitability Assessment of Coconut Growing Areas in the Coconut Triangle. Coconut Research Institute, Bandirippuwa Estate, Lunuwila.

4. Kasturi Bai K.V. \& Rajagopal V. (1999). Impact of drought on nut yield. In: Advances in Plant Physiology and Biochemistry of Coconut Palm. (Eds. V. Rajagopal \& A.Ramadasan) pp. 79- 85. Asian and Pacific Coconut Community, Jakarta, Indonesia.

5. Nainanayake A., Ranasinghe C.S. \& Tennakoon N.A. (2008). Effect of drip irrigation on canopy and soil temperature, leaf gas exchange, flowering and nut setting of mature coconut (Cocos nucifera L.). Journal of the National Science Foundation of Sri Lanka 36(1): 33-40.

6. Lakmini W.G.D., Nainanayake N.P.A.D. \& de Costa W.A.J.M. (2006). Biochemical changes of four different coconut (Cocos nucifera L.) forms under moisture stress conditions. The Journal of Agricultural Sciences (Sabaragamuwa) 2: 1-7.

7. Abeywardena V. (1979). Influence of watering on the yield of coconut. Ceylon Coconut Quarterly 30(3-4): 91-100.

8. Kapadiyal P.K., Koradiya U.A., Sarvaia R.B., Gandhi L.B., Bhambhaniya A.N. \& Raman S. (1998). Drip irrigation for coconut in South Saurashtra. In: Developments in Plantation Crop Research (Eds. N.M. Mathew \& C.K. Jacob) pp. 157- 159, Allied Publishing Co. Pvt Ltd., New Delhi, India.

9. Varadan K.M., Madhavachandran K., Joseph J. \& Jayakumar M. (1990). Effect of irrigation and mulch on soil moisture and soil temperature under coconut. Journal of Plantation Crops 18(1): 55-65.

10. Copeland E.B. (1931). The Coconut. $3^{\text {rd }}$ Edition. MacMillan and Co., London, UK.

11. Reyne A. (1948). De cocospalm. In: De Landbouw in de Indiche Archipel (Eds. C.J.J.Van Hall \& C. Van de Koppel) pp. 427- 525. Van Hoeve, The Hague, Netherlands.

12. Ohler J.G. (1984). Coconut, tree of life. In: FAO Plant Production and Protection Paper. pp. 14-35. Food and Agriculture Organization of the United Nations, Rome, Italy.

13. Jayakumar M., Saseendran S.A. \& Hemaprabha M. (1988). Crop coefficient for coconut (Cocos nucifera L.): a lysimetric study. Agricultural and Forest Meteorology 43: $235-240$.

13. Jayasekara K.S. \& Jayasekara C. (1993). Efficiency of water use in coconut under different soil/plant management systems. In: Advances in Coconut Research and Development (Eds. M.K Nair, H.H Khan, P. Gopalasundaran \& E.V.V Bhaskara Rao) p. 427. Oxford and IBH Publishing Co. Pvt Ltd., New Delhi, India.

14. Jayasekara C. (1992). Physiological studies on coconut. Transactions of Malaysian Society of Plant Physiology 3: 19-28.

15. Yusuf M. \& Varadan K.M. (1993). Water management studies on coconut in India. In: Advances in Coconut Research and Development (Eds. M.K Nair, H.H. Khan, P. Gopalasundaran \& E.V.V. Bhaskara Rao) pp. 337346. Oxford \& IBH Publishing Co. Pvt Ltd., New Delhi, India.

16. Ramadasan A. \& Kasturi Bai K.V. (1999). Water relation and screen coconut for drought tolerance. In: Advances in Plant Physiology and Biochemistry of Coconut Palm (Eds. V. Rajagopal \& A.Ramadasan) pp. 56-70. Asian and Pacific Coconut Community, Jakarta, Indonesia. 
17. Ping Lu, Woo K.C. \& Liu Z.T. (2002). Estimation of whole-plant transpiration of bananas using sap flow measurements. Journal of Experimental Botany 53(375): 1771-1779.

18. Smith D.M. \& Allen S.J. (1996). Measurement of sap flow in stems. Journal of Experimental Botany 47: 183-184.

19. Roupsard O., Bonnefond J., Irvine M., Berbigier P., Nouvellon Y., Dauzat J., Taga S., Hamel O., Jourdan C., Saint-André L., Mialet-Serra I., Labouisse J., Apron D., Joffre R., Braconnier S., Rouziere A., Navarro M. \& Bouillet J. (2006). Partitioning energy and evapotranspiration above and below a tropical palm canopy. Agricultural and Forest Meteorology 139: 252-268.

20. Granier A. (1987). Evaluation of transpiration in a Douglas fir stand by means of sap flow measurements. Tree Physiology 3: 309-320.

21. Granier A., Biron P. \& Lemoine D. (2000). Water balance, transpiration and canopy conductance in two beech stands. Agricultural and Forest Meteorology 100: 291-308.

22. Saugier B., Granier A., Pontailler J.Y., Dufrene E., Baldocchi D.D., Margolis H.A. \& Ryan M.G. (1997). Transpiration of a boreal pine forest measured by branch bag, sap flow and micrometeorological methods. Tree Physiology 17(8/9): 511-519.

23. Swanson R.H. \& Withfield D.A.W. (1981). A numerical analysis of heat pulse velocity theory. Journal of Experimental Botany 32: 221-239.

24. CohenY., Fuchs M. \& Green G.C. (1981). Improvement of the heat-pulse method for determining sap flow in trees. Plant and Cell Environment 4: 391-397.

25. Nadezhdina N. (1999). Sap flow index as an indicator of plant water status. Tree Physiology 19: 885-891.

26. Edward W.R.N., Becker P. \& Cermák J. (1996). A unified nomenclature for sap flow measurements. Tree Physiology 17: 65-67.

27. Green S.R. (1992). Radiation balance, transpiration and photosynthesis of an isolated tree. Agricultural and Forest Meteorology 64: 201-221.

28. Marshall D.C. (1958). Measurement of sap flow in conifers by heat transport. Plant Physiology 33: 385-396.

29. Moreno F., Fernández J.E., Clotheir B.E. \& Green S.R. (1996). Water use and root uptake by olive trees. Plant and Soil 184: 85-96.

30. Fernandez J.E., Palomo M.J., Diaz-Espejo A., Clothier B.E., Green S.R., Giron I.F. \& Moreno F. (2001). Heatpulse measurements of sap flow in olives for automating irrigation: tests, root flow and diagnostics of water stress. Agricultural Water Management 51: 99-123.

31. Green S.R., Clothier B.E., Caspari H.W. \& Neal S. (2002). Root zone processes, tree water use and the equitable allocation of irrigation water to olives. Geophysics Monograph 129: 337-345.

32. Moreno F., Fernández J.E., Clotheir B.E. \& Green S.R. (1996). Water use and root uptake by olive trees. Plant and Soil 184: 85-96.

33. Green S.R., McNaughton K.G. \& Clothier B.E. (1989). Nocturnal water use by kiwifruit and apples. Agricultural and Forest Meteorology 48: 251-261.

34. Green S.R. \& McNaughton K.G. (1997). Modeling the effective stomatal resistance for calculating transpiration from the apple tree. Agricultural and Forest Meteorology 83: $1-26$.

35. Green S.R. \& Clothier B.E. (1988). Water use of kiwifruit vines and apple trees by the heat-pulse technique. Journal of Experimental Botany 39: 115-123.

36. Caspari H.W., Green S.R. \& Edwards W.R.N. (1993). Transpiration of well watered and stressed Asian pears as determined by lysimetry, heat-pulse, and estimated by a Penman-Monteith model. Agricultural and Forest Meteorology 60: 13-27.

37. Alarcon J.J., Domingo R., Green S.R., Sanchez-Blanco M.J., Rodrigez P. \& Torrecillas A. (2000). Sap flow as an indicator of transpiration and the water status of young apricot trees. Plant and Soil 227: 77-85.

38. Burgess S.S.O., Adams M.A., Turner N.C., Beverly C.R., Ong C.K., Khan A.A.H. \& Bleby T.M. (2001). An improved heat pulse method to measure low and reverse rates of sap flow in woody plants. Tree Physiology 21: 589-598.

39. Cohen Y., Fuchs M. \& Green G.C. (1981). Improvement of the heat-pulse method for determining sap flow in trees. Plant and Cell Environment 4: 391-397.

40. Green S., Clothier B. \& Jardine B. (2003). Theory and practical application of heat pulse to measure sap flow. Agronomy Journal 95: 1371-1379.

41. Granier A., Biron B., Breda N., Pontailler J.Y. \& Saugier B. (1996). Transpiration of trees and forest stands: short and long term monitoring using sap flow methods. Global Change Biology 2: 265-274.

43. Wullschleger S.D. \& King A.W. (2000). Radial variation in sap velocity as a function of stem diameter and sap wood thickness in yellow poplar trees. Tree Physiology 20: $511-518$.

44. Vertessy R.A., Hatton T.J., Reece P., O'Sullivan S.K. \& Benyon R.G. (1997). Estimating stand water use of large mountain ash trees and validation of the sap flow measurement technique. Tree Physiology 17: 747-756.

45. Kasturi Bai K.V., Rajagopal V., Prabha C.D., Ratnambal M.J. \& Geroge M.V. (1996). Evaluation of coconut cultivars and hybrids for dry matter production. Journal of Plantation Crops 24: 23-28.

46. Moormann F.R. \& Panabokke C.R. (1961). Soils of Ceylon: a new approach to the identification and classification of the most important soil groups of Ceylon. Tropical Agriculturist 117: 3-79.

47. Dasanayake A.R., Somasiri L.L.W. \& de Silva G.G.R. (2005). Soils of the Low country Intermediate zone. In: Soils of the Intermediate Zone of Sri Lanka, Morphology Characterization and Classification (Eds. R.B. Mapa, A.R. Dasanayaka \& H.B. Nayakekorala). pp. 53-118. Special Publication No. 04, Soil Science Society of Sri Lanka, PO Box 10, Peradeniya.

48. Wullschleger S.D., Meinzer F.C. \& Vertessy R.A. (1998). A review of whole plant water use studies. Tree Physiology 18: 499-512.

49. Cohen Y. \& Li Y. (1996). Validating sap flow measurements in field-grown sunflower and corn. Journal of Experimental Botany 47: 1699-1707. 
50. Barrett D.J., Hatton T.J., Ash J.E. \& Ball M.C. (1995). Evaluation of the heat pulse velocity technique for measurement of sap flow in rain forest and eucalypt forest species of South-eastern Australia. Plant, Cell and Environment 18: 463-469.

51. Becker P. \& Edwards W. (1999). Corrected heat capacity of wood for sap flow: implication for measurements at night and in shade trees. Tree Physiology 18: 177-184.

52. Lide D.R. (1992). Handbook of Chemistry and Physics. pp. 6-10. $73^{\text {rd }}$ Edition. CRC Press Inc., Boca Raton, Florida, USA.

53. Tomlinson P.B. (2006). The uniqueness of palms. Botany Journal of Linnean Society 151: 5 - 14. 